\title{
Detection of White Spot Syndrome Virus in Brazil using Negative Staining, Immunoelectron Microscopy and Immunocytochemistry Techniques
}

\author{
Detección del Virus del Síndrome de Mancha Blanca en el Brasil Utilizando \\ Inmunomicroscopía e Inmunomarcación con Partículas de Oro Coloidal \\ "Hipolito, M.; "Catroxo, M. H. B.; *Martins, A. M. C. R. P. F.; *Melo, N.A.; "Pituco, E. M.; \\ ${ }^{*}$ Galleti, N.T.C.; *** Ranzani-Paiva, M. J. T.; ${ }^{* * *}$ Mouriño, J.L.P. \& ${ }^{* *}$ Ferreira, C.M.
}

HIPOLITO, M.; CATROXO, M.H.B.: MARTINS, A.M.C.R.P.F.; MELO, N.A.; PITUCO, E.M.; GALLETI, N.T.C.; RANZANIPAIVA, M.J.T.; MOURIÑO, J.L.P. \& FERREIRA, C.M. Detection of white spot syndrome virus in Brazil using negative staining, immunoelectron microscopy and immunocytochemistry techniques. Int. J. Morphol., 30(2):761-768, 2012.

SUMMARY: In this study thirty shrimp samples from commercial marine shrimp (L. vannamei) farms of southern region of Brazil were obtained. Hepatopancreas and shell scrapings fragments collected in these animals were processed by transmission electron microscopy using negative staining (rapid preparation), immunoelectron microscopy and immunocytochemistry (immunolabelling with colloidal gold particles) techniques. On the transmission electron microscopy a great number of white spot virus particles, ovoid or bacilliform-to-ellipsoid, measured 230-290 nm in length and $80-160 \mathrm{~nm}$ in diameter with intra-nuclear projections were visualized by the negative staining technique in 27 (90\%) out of 30 samples examined. Using immunoelectron microscopy technique, the anti-VP 664 serum agllutinated a large number of particles formed by antigen-antibody interaction. In the immunocytochemistry technique, the antigen-antibody reaction was styrongly marked by the particles of colloidal gold over the virus. Notably, this is the first report, to our knowledge, describing use of these microscopy techniques to study Brazilian L. vannamei marine shrimp samples; moreover, this methodology also appears to be a viable complementary tool for diagnosing the presence of the white spot virus within shrimp tissues. Importantly, these are the first photoelectron micrographs of the WSSV in Brazil.

KEYWORDS: White spot syndrome virus; Negative staining; Immunoelectron microscopy; Immunocytochemistry; Marine shrimp; Litopenaeus vannamei.

\section{INTRODUCTION}

The first experimental cultivation and production of penaeid shrimp was reported in the early 1970s, when French researchers in Tahiti developed techniques for the breeding and intensive farming of several exotic species, including Penaeus japonicus, P. monodon and later, $P$. vannamei and $P$. stylirostris, the latter later renamed Litopenaeus vannamei and L. stylirostris, respectively. In the late 1970s and early 1980s, L. vannamei and L. stylirostris were removed from their natural breeding area (west coast of Latin America between Mexico and Peru) to the United States, Belize, Nicaragua, Colombia, Venezuela, Philippines, China and Brazil (Rosenberry, 2002; Briggs et al., 2005).

In 1983, the white shrimp, popularly known as $L$. vannamei, was imported to Brazil for cultivation because it is a specie with high reproductive capacity, good adaptation to captivity, rapid growth, efficient feed conversion and high survival rates. However, it was only in 1995 that the commercial production of this exotic species began. Currently, the white shrimp accounts for 95\% of Brazilian marine shrimp production (Briggs et al.), having reached 76,000 tons in 2004 (FAO, 2006). However, shrimp farming in the Americas and worldwide has been severely impacted by various types of pathogenic viruses, notably by the White Spot Virus (Paez-Osuna, 2001; Lightner, 2005a, b; Sanchez-Martinez et al., 2007).

The White Spot Disease (WSD), or White Spot Syndrome, is caused by the virus from which its name derives (WSSV). It has this name because of the 
HIPOLITO, M.; CATROXO, M.H.B.: MARTINS, A.M.C.R.P.F.; MELO, N.A.; PITUCO, E.M.; GALLETI, N.T.C.; RANZANI-PAIVA, M.J.T.; MOURIÑO, J.L.P. \& FERREIRA, C.M. Detection of white spot syndrome virus in Brazil using negative staining, immunoelectron microscopy and immunocytochemistry techniques. Int. J. Morphol., 30(2):761-768, 2012.

characteristic of this disease that is the formation of white spots in the exoskeleton, in the rostrum and in the epidermis. This virus belongs to the genus Whispovirus and the family Nimaviridae (Mayo, 2002), but was initially classified as a member of the Baculoviridae family (Wang et al., 1995).

The disease emerged in Mainland, China between 1992 and 1993, and was quickly dispersed throughout the Asian continent by infected seeds and animal stock. The first outbreaks were reported in 1993 on a Macrobrachium japonicus farm in Japan (Nakano et al., 1994). Shrimp exhibiting the characteristic signs and histopathology of white spot disease were also reported in Korea, India, the Philippines and the USA, and this same virus also struck shrimp farms in southeast Europe (1997) and the Middle East (1999) (Lightner,2005 b). During 1999, the disease had a serious impact on the shrimp industry in Central and South America and resulted in large losses, especially in Ecuador, which was, until then, one of the major world producers. Between 2000 and 2001, the WSSV reached Spain and Australia; however, cases of successful containment and eradication have been reported, and for both events, the import and utilization of infected frozen shrimp as animal feed was implicated as the route of introduction (Lightner, 2005b; Sánchez-Martínez et al., 2007). In November 2004, commercial farms of L. vannamei produced in the town of Laguna in southern Brazil were infected with WSSV. Mortality rates reached $90 \%$, causing losses of more than 3 million USD. This first outbreak in Brazil was reported by OIE on January 20, 2005 and, more recently, a new outbreak of the virus has been reported on farms in Ceará, northeast Brazil (CEI, 2005; Seiffert et al., 2005; Cavalli et al., 2008).

During the last two decades, a combination of poor management practices and intensive penaeid shrimp farming has led to the emergence of several viral diseases. The WSD is reported as the most devastating among these viral diseases and can cause $100 \%$ mortality of the farmed shrimp (Lightner 2005 a, b; Sanchez-Martinez et al.). This virus infects many tissues, multiplies in the nucleus of the target cell, leads to cellular disintegration at the final phase of infection and causes the destruction of the infected tissues (Flegel, 1997; Leu et al., 2009).

The WSSV has a cylindrical shape, is slightly elliptical, measures between $121 \pm 9 \mathrm{~nm}$ x 26士276 nm (Wongteerasupaya et al., 1995) and is a double-stranded DNA virus with a genome of approximately $300 \mathrm{bp}$. The virion is composed of a trilaminar nucleocapsid enveloped by a membrane that often shows a tail-like extension $(\mathrm{Wu}$
\& Yang, 2006). The White Spot Syndrome Virus 1 is the only representative of the genus Whispovirus described, showing no apparent immunologic diversity, although some genetic polymorphism has been observed in several isolates (ICTVdB, 2007).

One of the characteristics of this virus is the ability to infect numerous hosts, including a great variety of crustaceans (shrimps, lobsters, copepods), insects and larvae; in penaeid shrimp specifically, the virus has been detected at all stages of growth (Chang et al., 1998). Transmission can be horizontal through water or by the practice of cannibalism of infected shrimps, or vertically, from females to eggs, resulting in infected larvae (Lo et al., 1997).

In accordance with recommendations by the WOAH/OIE (2003a, b), in situ hybridization and nested polymerase chain reaction are used for the detection and diagnosis of WSD. The presence of the whole virus is not required for these techniques, because viable DNA segments can be amplified by specific primers. Other techniques, such as histology and electron microscopy, are used for the observation of lesions and visualization of the virus and, more recently, methods based on antibody-based pathogen detection have been used (Lightner 2005a).

Specifically, the use of transmission electron microscopy (TEM) allows for the study of structural and morphological details of the virus and the subcellular constituents with which these organisms may or may not be associated. The use of TEM along with immunoelectron microscopy (IEM) and immunocytochemistry is particularly beneficial when the number of virus particles in a sample is very low, since it allows for the identification of the virus not only by a specific antigen-antibody reaction but also via morphology (Katz \& Kohn, 1984; Hayat \& Miller, 1990). Furthermore, it allows for the detection and identification of antigens from virus-induced structures and their localization in infected cells, serotyping of viral strains (Kjeldsberg, 1986) and the determination of antigenic variants of an isolate (Patterson \& Oxford, 1986). These techniques can be used individually, in series or in parallel, in order to confer increased sensitivity or specificity of virus detection.

The objective of this study was to demonstrate the viability of negative staining, immunoelectron microscopy and immunocytochemistry (immunolabeling with colloidal gold particles) as a complementary diagnosis of white spot disease in field samples. 
HIPOLITO, M.; CATROXO, M.H.B.: MARTINS, A.M.C.R.P.F.; MELO, N.A.; PITUCO, E.M.; GALLETI, N.T.C.; RANZANI-PAIVA, M.J.T.; MOURIÑO, J.L.P. \& FERREIRA, C.M. Detection of white spot syndrome virus in Brazil using negative staining, immunoelectron microscopy and immunocytochemistry techniques. Int. J. Morphol., 30(2):761-768, 2012.

\section{MATERIAL AND METHOD}

Samples. Thirty shrimp samples from commercial marine shrimp (L. vannamei) farms of southern Brazil (North coast of Santa Catarina), in growout phase, were obtained between 2006 and 2007. All animals showed white spots on the exoskeleton, in the rostrum and in the epidermis. The shrimp were desensitized by refrigeration and frozen. Fragments of the hepatopancreas and shell scrapings were suspended in phosphate buffer (0.1 M, pH 7.0).

Negative Staining Technique. Drops of the obtained suspensions were placed on metal grids, previously covered with colloidal film and stabilized with carbon. Subsequently, the grids were drained with filter paper and negatively contrasted with $2 \%$ ammonium molybdate, pH 5.0 (Brenner \& Horne, 1959; Hayat \& Miller, Madeley, 1997).

Immunoelectron Microscopy Technique (IEM). The copper grids were prepared as described above, sensitized for 15 minutes with primary anti-WSSV polyclonal antibody against protein VP664 (Abcam ${ }^{\circledR}$, diluted at 1:200) and were washed with PBS buffer. Upon incubation with the WSSV viral suspension for 10 minutes, grids were washed successively with distilled water and negatively contrasted with ammonium molybdate under the same conditions (Katz \& Kohn; Hayat \& Miller; Wu \& Yang).

Immunocitochemistry Technique (Immunolabeling with colloidal gold particles - ISCG). Previously prepared copper grids were incubated for 30 minutes in drops of viral suspension, sensitized with the same antibody diluted at 1:80 and washed with PBS buffer. Grids were incubated sequentially with secondary antibody (protein A conjugated with colloidal gold particles of $10 \mathrm{~nm}$ in diameter (Electron Microscopy Sciences () diluted 1:20 in 0.5\% PBS for 30 minutes and negatively contrasted with ammonium molybdate (Knutton, 1995).

The samples were examined by transmission electron microscopy using a Philips EM 208 microscope. As a technical control, for every 10 samples incubated, one was treated as described previously, but the antibody was replaced by distilled water.

\section{RESULTS}

Negative Staining Technique. Analyses performed by TEM revealed a large number of particles with ovoid or bacilliform-to-ellipsoid morphology, measuring about 230$290 \mathrm{~nm}$ long and 80-160 nm in diameter, showing intranuclear projections (Fig. 1) in 27 (90\%) of 30 samples examined (Table I).

In some samples, the capsids were empty due to nucleocapsid release, and the viral envelopes were separated from their virions. In other samples, only the nucleocapsids were observed, revealing grooves located along the major axis (Fig. 2). Another samples showed ring-like particles connected to the virion (Fig. 3).

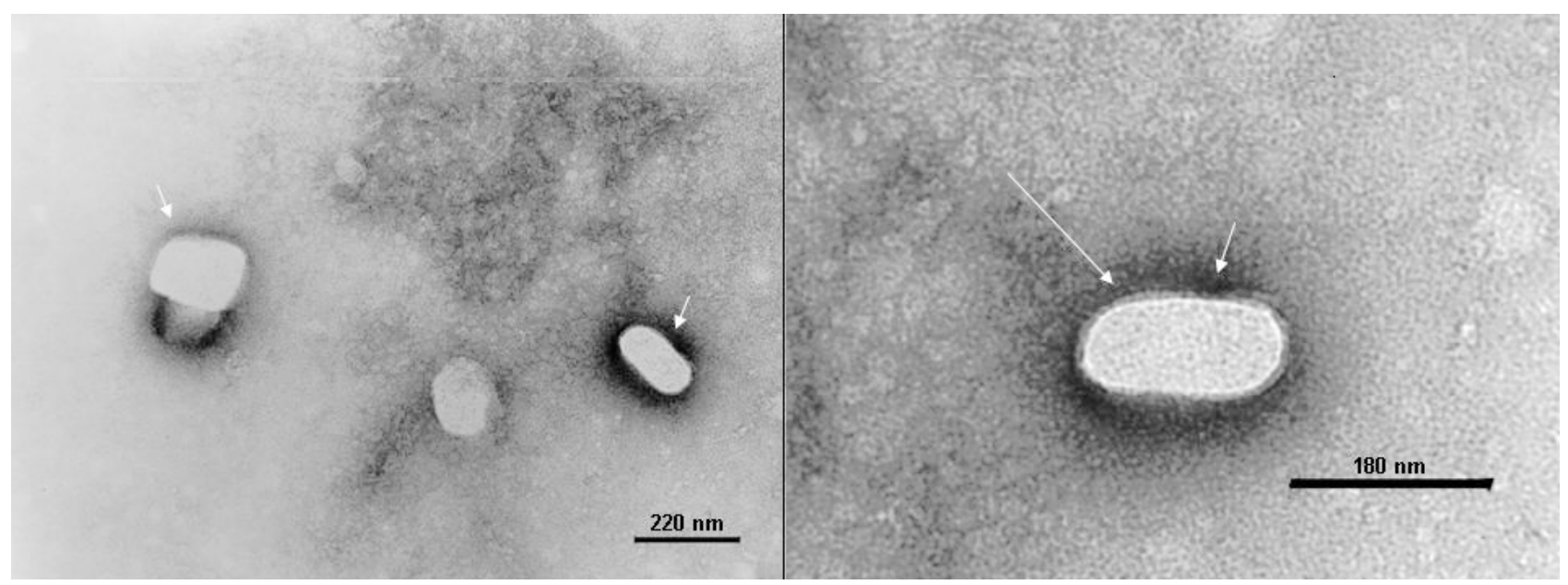

Fig. 1. Photoelectronmicrograph of the WSSV viral suspension from L. vannamei hepatopancreas. Oval-shaped and bacilliform particles (large arrow) and outer envelope (lower arrow) 
Immunoelectron Microscopy Technique. Results from IEM showed a positive reaction in $90 \%$ of the samples analyzed (Table 1). The anti-VP664 serum agglutinated a large number of particles (i.e., antibody-virus aggregate) (Fig. 4a).

Immunocytochemistry Technique. In the immunocytochemistry technique, the antigen-antibody reaction was increased by colloidal gold particles that labeled Whispovirus effectively (Figs. 4b, c, d), thus confirming the results previously obtained by negative staining and immunoelectron microscopy techniques (Table 1).

Fig. 2. Photoelectronmicrograph of the WSSV viral suspension from L. vannamei shells showing WSSV nucleocapsids with grooves. Negative staining technique.
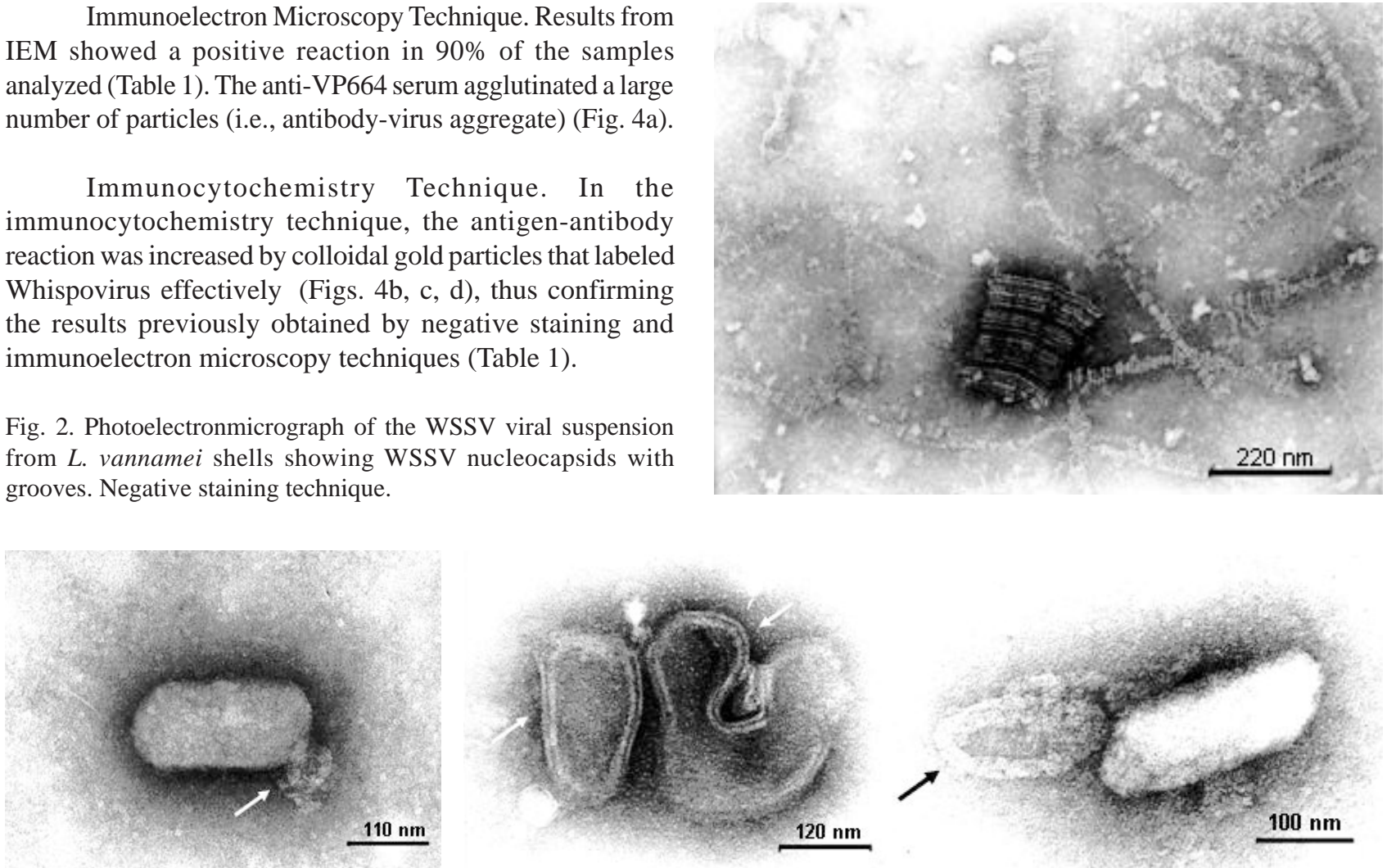

Fig. 3. Photoelectronmicrograph of the WSSV viral suspension showing ring-like particles connected to the virion (arrows). Negative staining technique.

\begin{tabular}{|c|c|c|c|c|c|c|c|}
\hline Sample & NS & IEM & ISCG & Sample & NS & IEM & ISCG \\
\hline 1 & + & + & + & 16 & + & + & + \\
\hline 2 & + & + & + & 17 & + & + & + \\
\hline 3 & + & + & + & 18 & - & - & - \\
\hline 4 & + & + & + & 19 & + & + & + \\
\hline 5 & + & + & + & 20 & + & + & + \\
\hline 6 & + & + & + & 21 & + & + & + \\
\hline 7 & + & + & + & 22 & + & + & + \\
\hline 8 & + & + & + & 23 & + & + & + \\
\hline 9 & + & + & + & 24 & + & + & + \\
\hline 10 & + & + & + & 25 & + & + & + \\
\hline 11 & + & + & + & 26 & + & + & + \\
\hline 12 & + & + & + & 27 & - & - & - \\
\hline 13 & + & + & + & 28 & - & - & - \\
\hline 14 & + & + & + & 29 & + & + & + \\
\hline 15 & + & + & + & 30 & + & + & + \\
\hline
\end{tabular}

Table I. Comparation of results obtained by applying the negative staining (NS), i m m unoelectron microscopy (IEM) and immunocytochemistry (ISCG) techniques for WSSV. Samples of marine shrimp, Santa Catarina State, Brazil, 2007-08. 

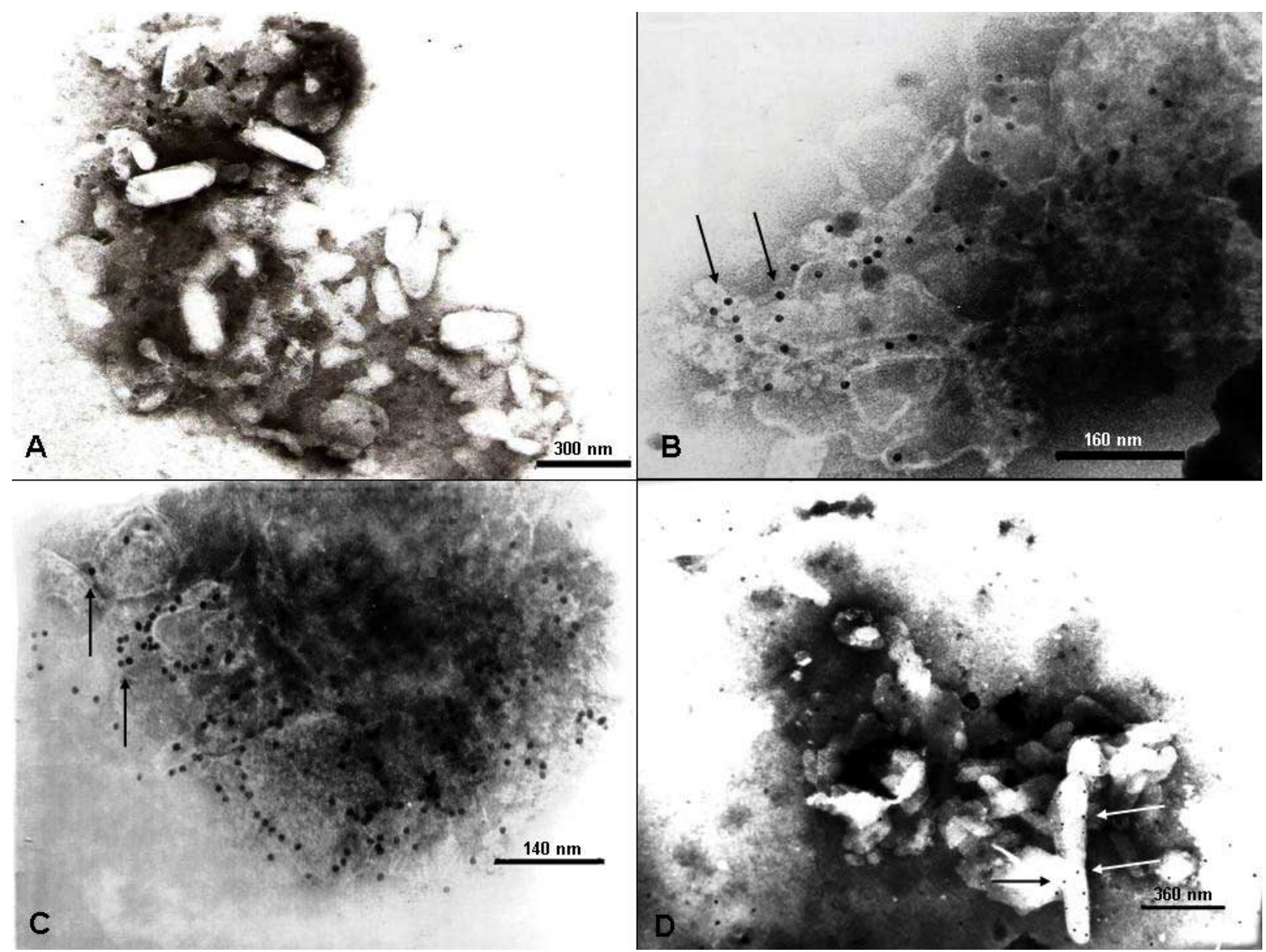

Fig. 4. Immunoelectron microscopy and immunocytochemistry techniques. A - WSSV particles aggregated to the immune complex. B, C, D - a strong antigen-antibody interaction was evidenced by the gold particles on the virion (arrows).

\section{DISCUSSION}

In the present paper thirty shrimp samples from commercial marine shrimp (L. vannamei) farms of southern Brazil were obtained.

The examined animals presented formation of white spots in the exoskeleton, in the rostrum and in the epidermis.

Similarly, these symptons were described by other authors in other shrimps species (Nakano et al.; Lo et al.; Seiffert et al.; Cavalli et al.; Muller et al., 2010).

Analysis performed by TEM revealed a large number of particles with ovoid or bacilliform-to-ellipsoid morphology, showing intranuclear projections and ring-like particles connected to the virion in 27 (90\%) out of 30 samples examined.

These morphological aspects also were been observed by other authors in ultrastructural study for the WSSV (Chou et al., 1995; Durand et al., 1997; Wang et al., 2000; Rajendran et al., 2004; Van Hulten et al., 2001; Afsharnasab, 2006; Escobedo et al., 2008; Zhu et al., 2009).

In other samples only the nucleocapsids were observed, revealing grooves located along the major axis. These aspects also has been related by other researchers (Durand et al., 1997; Afsharnasab, 2006).

In the immunoelectron microscopy technique the anti VP 664 serum agglutinated a large number of particles formed by antigen antibody interaction. 
HIPOLITO, M.; CATROXO, M.H.B.: MARTINS, A.M.C.R.P.F.; MELO, N.A.; PITUCO, E.M.; GALLETI, N.T.C.; RANZANI-PAIVA, M.J.T.; MOURIÑO, J.L.P. \& FERREIRA, C.M. Detection of white spot syndrome virus in Brazil using negative staining, immunoelectron microscopy and immunocytochemistry techniques. Int. J. Morphol., 30(2):761-768, 2012.

This technique was successfully applied to agglutinate various types of viruses, such as paramyxovirus, retrovirus and coronavirus (Catroxo et al., 2010).

Despite the fact that these are non-purified field samples, satisfactory distribution of numerous gold particles can be observed throughout the entire nucleocapsid as opposed to one specific region when we apply the immunocytochemistry technique, confirming the results fo the negative staining and immunoelectron microscopy techniques.

In other experiments, WSSV particles were enhanced by this technique (Wu \& Yang; Liu et al., 2006; Tsai et al., 2006; Chang et al., 2008).

The VP664 protein is a giant polypeptide chain that functions as a structural protein and, due to its size, is considered to be the largest protein isolated thus far from shrimp; this protein provides the basis for the production of polyclonal antisera. Encoded by an open reading frame (ORF) of 18,234 nucleotides, it generates a long polypeptide of 6077 amino acids with an as yet unknown function (Leu et al., 2005).

In this study, we used the anti-VP664 serum to confirm a positive result from $L$. vanname $i$ in shell scrapings and hepatopancreas samples. Because the shrimp organs were flaccid and easily perishable, they were immediately frozen at $-20^{\circ} \mathrm{C}$ and processed in twenty days. Notably, the NS, IM and ISCG techniques were performed using frozen field samples, wherein the number of viral particles is smaller than that obtained from cell culture, a procedure used to enrich the material for subsequent use by TEM. It is evident that the process of freezing the samples immediately after collection, did not interfere in the result indicating that the virus particle remained integrated.

The results in Table I, show a perfect concordance between the samples, showing a perfect affinity between these techniques.

All techniques used herein were sensitive, thus demonstrating their value at a diagnostic level.

Electron microscopy is becoming increasingly important in the diagnosis of viral agents (Hayat \& Miller) and constitutes an essential tool in the detection of emerging diseases by providing a rapid diagnosis of viral infections through processing of clinical samples (Gelderblom \& Mãnnel, 2003; Leu et al.). The association of TEM with serodiagnostic methods using mono- or polyclonal antisera enriches this methodology and stands out as an accurate and fast diagnostic tool.

Notably, this is the first report, to our knowledge, describing use of these microscopy techniques to study Brazilian L. vannamei marine shrimp samples; moreover, this methodology also appears to be a viable complementary tool for diagnosing the presence of the white spot virus within shrimp tissues.

Importantly, these are the first photoelectron micrographs of the WSSV in Brazil.

ACKNOWLEDGEMENT. This work was performed with the financial support of Fundação de Amparo à Pesquisa do Estado de São Paulo (FAPESP 07/58734-9).

HIPOLITO, M.; CATROXO, M.H.B.: MARTINS, A.M.C.R.P.F.; MELO, N.A.; PITUCO, E.M.; GALLETI, N.T.C.; RANZANIPAIVA, M.J.T.; MOURIÑO, J.L.P. \& FERREIRA, C.M. Detección del virus de síndrome de Mancha Blanca en Brazil utilizando inmunomicroscopia e inmunomarcación con partículas de oro coloidal. Int. J. Morphol., 30(2):761-768, 2012.

RESUMEN: Se obtuvieron para el estudio 30 muestras de camarones marinos comerciales (L. vannamei) de las granjas de la región sur de Brasil. Fueron procesados fragmentos de hepatopáncreas y raspados internos del cefalotórax recogidos en estos animales por microscopía electrónica de transmisión con tinción negativa (preparación rápida), inmunomicroscopía y técnicas de inmunocitoquímica (inmunomarcación con partículas de oro coloidal). En la microscopía electrónica de transmisión de un gran número de partículas de virus de la mancha blanca, ovoide o elipsoidal a baciliformes, medían 230-290 nm de longitud y 80-160 nm de diámetro. En 27 (90\%) de las 30 muestras examinadas intra-nuclear proyecciones se visualizaron mediante la técnica de tinción negativa. Utilizando una técnica de inmunomicroscopía electrónica, el anti-suero VP 664 reunió a un gran número de partículas formadas por la interacción antígenoanticuerpo. En la técnica de inmunocitoquímica, la reacción antígeno-anticuerpo fue fuertemente reforzada por las partículas de oro coloidal en los virus. En particular, en Brasil este es el primer informe, a nuestro entender, que describe el uso de estas técnicas de microscopía en muestras de camarón marino L. vanamei. Además, esta metodología también parece ser una herramienta complementaria viable para diagnosticar la presencia del virus de la mancha blanca en tejidos de camarón. Es importante destacar que estas son las primeras fotos en microscopia electrónica del WSSV obtenidas en Brasil.

PALABRAS CLAVE: Vírus de la mancha blanca, tinción negativa, inmunomicroscopía electrónica; inmunocitoquímica; camarón marino, Litopenaeus vannamei. 
HIPOLITO, M.; CATROXO, M.H.B.: MARTINS, A.M.C.R.P.F.; MELO, N.A.; PITUCO, E.M.; GALLETI, N.T.C.; RANZANI-PAIVA, M.J.T.; MOURIÑO, J.L.P. \& FERREIRA, C.M. Detection of white spot syndrome virus in Brazil using negative staining, immunoelectron microscopy and immunocytochemistry techniques. Int. J. Morphol., 30(2):761-768, 2012.

\section{REFERENCES}

Afsharnasab, M. Identification of white spot syndrome disease (WSSV) by electron microscopy in Penaeus indicus. Pajouhesh \& Sazandegi.,66:8-13, 2006.

Brenner, S. \& Horne, R. W. A negative staining method for high resolution electron microscopy of viruses. Biochem. Biophys. Acta., 34:103-10, 1959.

Briggs, M.; Funge-Smith, S.; Subasinghe, R.P. \& Philips, M. Introductions and movements of two penaeid shrimp species in Asia and the Pacific. FAO Fisheries Technical Paper. $\mathrm{N}^{\circ}$ 476. Rome, 2005.

Catroxo, M. H. B.; Taniguchi, D. L.; Melo, N. A.; Milanelo, L.; Petrella, S.; Alves, M.; Martins, A.M.C. R.P.F. \& Rebouças, M. M. Viral research in Brazilian owls (Tyto alba and Rhinoptynx clamator) by transmission electron microscopy. Int. J. Morphol., 28(2):627-36, 2010.

Cavalli, L.S.; Marins, L.F.; Netto, S. \& Abreu, P.C. Evaluation of White Spot Syndrome (WSSV) in wild shrimp after a major outbreak in shrimp farms at Laguna, Southern Brazil. Atlântica, 30(1):45-2, 2008.

CEI Center for Emerging Issues. White Spot Disease, Brazil. http:/ /www.aphis.usda.gov/animal_health/emergingissues/ impactworksheets/iw_2005_files/foreing/ wsdbrazil012105.htm, 2005.

Chang, P.S; Lo, C.F. \& Wang, Y.C. The effect of ultraviolet irradiation, heat, $\mathrm{pH}$, ozone, salinity and chemical disinfectants on the infectivity of white spot syndrome baculovirus. Aquaculture, 166(1-2):1-17, 1998.

Chang, Y-S.; Liu, W-J.; Chou, T-L.; Lee, Y-T.; Lee, T-L.; Huang, W-T.; Kou, G-H. \& Lo, C-F. 2008. Characterization of white spot syndrome virus envelope protein VP51A and its interaction with viral tegument protein VP26. J. Virol., 82(24):12555-64, 2008

Durand, S.; Lightner, D.V.; Redeman, R.M. \& Bonami, J.R. Ultrastructure and morphogenesis of white spot syndrome baculovirus (WSSV). Dis. Aquat. Organ., 29:205-11, 1997.

Escobedo, C.M.B.; Alday, V.S.; Wille, M.; Sorgeloos, P.; Pensaert, M.B. \& Nauwynck, H.J. A review on the morphology, molecular characterization, morphogenesis and pathogenesis of white spot syndrome virus. J. Fish Dis., 31:1-18, 2008.

FAO - State of world aquaculture. FAO Fisheries Technical Paper. No 500. Rome, 2006.

Flegel, T.W. Special topic review: major viral diseases of the black tiger prawn (Penaeus monodon) in Thailand. World $J$. Microbiol.. Biotechnol., 13:433-42, 1997.
Gelderblom H.R. \& Mãnnel, A. Diagnostic electron microscopy in infectious diseases: up date 2003. Microsc. Microanal., 9 (suppl.3):432-3, 2003.

Hayat, M.A. \& Miller, S.E. Negative Staining. Mc. Graw-Hill Publ. Company. New York, 1990.

ICTVdB The Universal Virus database, version 3. http:// www.ncbi.nlm.nih.gov/ICTVdb/ICTVdB, 2007. Accessed Feb. 2008 .

Katz, D. \& Kohn, A. Immunosorbent Eletron Microscopy for Detection of Viruses. Adv. Virus Res., 29:169-94, 1984.

Kjeldsberg, E. Use pf Gold IgG Complexes and Human Antisera for Electron Microscopy Identification of Hepatitis A Virus and Polioviruses. J. Virol. Meth., 13: 207, 1986.

Knutton, S. Electron Microscopy Methods in Adhesion. Methods Enzimol., 253:145-58, 1995.

Leu, J.H.; Yang, F.; Zhang, X.; Xu, X.; Kou, G.H. \& Lo C.F. Whispovirus. In: Etten, J.L.V. (ed.) Lesser Known Large dsDNA Viruses. n. 328. Cur. Top. Microbiol. Immunol., 2009.

Leu, J.H.; Tsai, J.M.; Wang, H.C.; Wang, A.H.C.; Wang, C.H.; Kou, G.H. \& Lo, C.F. The unique stacked rings in the nucleocapsid of the White Spot Syndrome Virus virion are formed by the major structural Protein VP664, the largest viral structural protein ever found. J. Virol., 79(1):140-9, 2005b.

Lightner, D.V. Biosecurity in Shrimp Framing: Pathogen Exclusion through Use of SPF Stock and Routine Surveillance. J. World. Aquac. Soc., 36 (3):229-248, 2005 a.

Lightner, D.V, The Penaeid Shrimp Viral Pandemics due to IHHNV, WSSV, TSV and YHV: History in the Americas and Current Status. In: Walker, P.J.; Lester, R.G. \& BondadReantaso M.G. (eds). Diseases in Asian Aquacultu. Crustacean Pathology and Diseases, Fish Health Section. Asian Fisheries Society, Manila, 2005. http:// www.lib.noaa.gov/japan/aquaculture/proceedings/report32/ lightner_corrected.pdf Accessed May 2009.

Liu, Y.; Wu, J.; Song, J.; Sivaraman, J. \& Hew, C.L. Identification of a novel nonstructural protein, VP9, from white spot syndrome virus: its structure reveals a ferredoxin fold with specific metal binding sites. J. virol., 80(21):10419-27, 2006.

Lo, C.F.; Ho, C.H.; Chen, C.H.; Liu, K.F.; Chiu, Y.L.; Yeh, P.Y.; Peng, S.E.; Hsu, H.C.; Liu, HC, Chang, C.F.; Su, M.S.; Wang, C.H. \& Kou, G.H. Detection in tissue tropism of white spot syndrome baculovirus (WSBV) in capture brooders of Penaeus monodon with a special emphasis on reproductive organs. Dis. Aquat. Org., 30:53-72, 1997. 
HIPOLITO, M.; CATROXO, M.H.B.: MARTINS, A.M.C.R.P.F.; MELO, N.A.; PITUCO, E.M.; GALLETI, N.T.C.; RANZANI-PAIVA, M.J.T.; MOURIÑO, J.L.P. \& FERREIRA, C.M. Detection of white spot syndrome virus in Brazil using negative staining, immunoelectron microscopy and immunocytochemistry techniques. Int. J. Morphol., 30(2):761-768, 2012.

Madeley, C. R. Origins of electron microscopy and viral diagnosis. J. Clin. Pathol., 50(6):454-6, 1997.

Mayo, M.A. A summary of taxonomic changes recently approved by ICTV. Arch. Virol., 147:1655-63, 2002.

Muller, I.C.; Andrade, T.P.D.; Tang-Nelson, K.F.J.; Marques, M.R.F. \& Lightner, D.V. Genotyping of white spot syndrome virus (WSSV) geographical isolates from Brazil and comparison to other isolates from the Americas. Dis. Aquat. Org., 88(2):918,2010 .

Nakano, H.; Koube, H.; Umezawa, S.; Momoyama, K.; Hiraoka, M.; Inouye, K. \& Oseko, N. Mass mortalities of cultured kuruna shrimp, Penaeus japonicus, in Japan in 1993: Epizootiological survey and infection trials. Fish Pathol., 29:135-9, 1994.

Paez-Osuna, F. The Environmental Impact of Shrimp Aquaculture: Causes, Effects and Mitigating Alternatives. J. Environ. Manage., 38(1):131-40, 2001.

Patterson, S. \& Oxford, J.S. Analysis of Antigenic Determinants on Internal and External proteins of Influenza Virus and Identification of Antigenic Subpopulations of Virion in Recent Field Isolates Using Monoclonal Antibodies and Immunogold Labeling. Arch. Virol., 88:189-202, 1986.

Rajendran, K.V.; Mukherjee, S.C.; Vijayan, K.K.; Jung, S.J.; Kim, Y.J. \& Oh, M.J. A comparative study of white spot syndrome virus infection in shrimp from India and Korea. J. Invert. Pathol., 84:173-6, 2004.

Rosenberry, B. World shrimp farming. Shrimp News International, 276pp, 2002.

Sanchéz-Matinez, J.G.; Aguirre-Gusman, G. \& Mejia-Ruíz, H. White spot syndrome virus in cultured shrimp: a review. Aquac. Res., 38:1339-54, 2007.

Seiffert, W.Q.; Winckler, S. \& Maggioni, D. A mancha branca em Santa Catarina. Panorama da Aqüicultura, 15(87):51-3, 2005.

Tsai, J-M.; Wang, H-C.; Leu, J-H.; Wang, A. H-J.; Zhuang, Y.; Walker, P.J.; Kou, G-H. \& Lo, C-F. Identification of the nucleocapsid, tegument, and envelope proteins of the shrimp white spot syndrome virus virion. J. Virol., 80:3021-9, 2006.

Van Hulten, M.C.W.; Witteveldt, J.; Peters, S.; Kloosterboer, N.; Tarchini, R.; Fiers, M.; Sandbrink, H.; Lankhorst, R.K. \& Vlak, J.M. The white spot syndrome virus DNA genome sequence. Virol., 286: 7-22, 2001.

Wang, C.H,; Lo, C.F.; Leu, J.H.; Chou, C.M.; Yeh, P.Y.; Chou, H.Y.; Tung, M.C.; Chang, C.F,; Su, M.S. \& Kou, G.H. Purification and genomic analysis of baculovirus associated with White spot syndrome (WSBV) of Penaeus monodon. Dis. Aquac. Org., 23:239-242, 1995.
Wang, Q.; Poulos, B.T. \& Lightner, D.V. Protein analysis of geographic isolates of shrimp white spot syndrome virus. Arch. Virol., 145:263-74, 2000.

WOAH/OIE World Organization for Animal Health http:// www.oie.int/eng/normes/fcode/A_summry.htm, 2003 a. Accessed Mar 2009.

WOAH/OIE World Organization for Animal Health http:// www.oie.int/eng/normes/fmanual/A_summry.htm, $2003 \mathrm{~b}$. Accessed Mar 2009.

Wongteerasupaya, C.; Vickers, J.E.; Sriurairatana, S.; Nash, C.L.; Akarajamorn, A.; Boonsaeng, V.; Panyirn, S.; Tassanakajon, A.; Withyachumnarnkul, B. \& Flegel, T.W. A non-occluded, systemic baculovirus that occurs in cells of ectodernlal and mesodermal origin and caused high mortality in the black tiger prawn Penaeus monodon. Dis. Aquat. Org., 21:69-77, 1995.

Wu, C. \& Yang, F. Localization studies of two white spot syndrome virus structural proteins VP51 and VP76. Virol. J., 3:76, 2006.

Zhu, F.; Du, H.; Miao, Z-G.; Quan, H-Z. \& Xu, Z-R. Protection of Procambarus clarkii against white spot syndrome virus using inactivated WSSV. Fish Sellfish Immunol., 26:685-90, 2009.

\section{Correspondence to:}

Prof. Dr. Marcio Hipolito

Interinstitutional Laboratory of Health in Aquaculture (LISA)

Research and Development Center in Animal Health

Biological Institute of São Paulo

Av. Conselheiro Rodrigues Alves, 1252

CEP 04014-002

Vila Mariana

São Paulo, SP,

BRAZIL

Email: hipolito@biologico.sp.gov.br

Received: 02-03-2012

Accepted: 18-04-2012 